\title{
Review: The Use of Bench-Scale Tests to Determine Toxic Organic Compounds in Fire Effluents and to Subsequently Estimate Their Impact on the Environment
}

Kelly Peeters (D), InnoRenew CoE, Livade 6, 6310 Izola, Slovenia and Andrej

Marušič Institute, University of Primorska, Muzejski trg 2, 6000 Koper, Slovenia

Matija Ursič, Slovenian National Building and Civil Engineering Institute (ZAG), Dimičeva 12, 1000 Ljubljana, Slovenia

Črtomir Tavzes (D, InnoRenew CoE, Livade 6, 6310 Izola, Slovenia and Andrej

Marušič Institute, University of Primorska, Muzejski trg 2, 6000 Koper,

Slovenia

Friderik Knez, Slovenian National Building and Civil Engineering Institute (ZAG), Dimičeva 12, 1000 Ljubljana, Slovenia

Received: 25 May 2020/Accepted: 11 November 2020

\begin{abstract}
Generated fire effluents are toxic and responsible for the majority of fire deaths and injuries. Therefore, measures of fire safety and the assessment of toxic effects of fires on humans, which are the key factors to assess fire hazards, have been researched in the last decades. However, it is more and more recognized that there is also a need to assess the environmental impact of toxic compounds within fire effluents. Since ecotoxicology investigates the toxic effects of fire effluents on populations, interactions between ecology and toxicology are very important. These interactions may be complex and may involve research of food chains with several different trophic levels. This makes tracing of toxicants, to obtain reliable results, a real challenge. To tackle it, the bench-scale test is a cheaper and less complex method than large-scale fire simulations. Progress in the field of ecotoxicological studies is important because long-term exposure from the environment and bioaccumulation of toxic compounds in the human food chain may cause indirect health effects on humans. It is also an important tool for the general protection of the environment and biodiversity. Last, with data obtained from these studies, databases for the Life Cycle Assessment of construction materials can be improved.
\end{abstract}

Keywords: Bench-scale tests, Ecotoxicology, Fire effluents, Toxicity

\footnotetext{
*Correspondence should be addressed to: Kelly Peeters, E-mail: kelly.peeters@innorenew.eu
} 


\section{Introduction}

A fire, involving organic substances, releases both heat and smoke. It is an uncontrolled, chaotic process in which conditions change rapidly. Depending on the fire's specific conditions, many diverse chemical compounds are produced in varying amounts. The substances, contained within fire effluents, can adversely affect human health. In principle, they are divided in four groups: asphyxiants (e.g. carbon monoxide, carbon dioxide, hydrogen cyanide), irritants (e.g. ammonia, hydrogen chloride, nitrogen oxides, phenol, sulphur dioxide), allergens (e.g. isocyanates), and carcinogens (e.g. polycyclic aromatic hydrocarbons [PAHs], dioxins, furans, certain heavy metals) [1]. The combustion of organic materials, particularly if it is incomplete, may also give rise to more complex molecules in the smoke plume, which may typically include longer carbon chains and multiple carbon-rings. The acute toxicity of these compounds is generally low and may not pose a direct health hazard during exposure [2]. In addition, fire effluents contain soot particles (particulate matter $[\mathrm{PM}]$ ) that can penetrate deep into the lungs while carrying other, less mobile compounds. Many of these released substances are not only potentially toxic to humans but also to flora and fauna, which renders fire and fire effluent not only able to cause incapacitation, injury or death in people but also a potentially potent environmental hazard [3].

The serious consequences of disasters in recent years (e.g. California wildfires [2019], Amazon rainforest wildfires [2019] and forest fires in Australia [2020]) have highlighted the environmental impact of fires as a real threat. The emission and re-deposition of fire effluent components with carcinogenic or mutagenic properties can contribute to persistent contamination of the atmosphere, soil and water bodies, resulting in severe ecological damage [4-6]. Aerosols can be carried over long distances of tens or even hundreds of kilometres by wind before they settle on the ground or water surface. Depending on their chemical composition, their effects may include: acidification of lakes and streams, change in the nutrient balance in coastal waters and large river basins, depletion of nutrients in soil, damage to sensitive forests and farm crops or effects on diversity of ecosystems [7]. Aerosolised solid particles with less than $10 \mu \mathrm{m}$ in diameter pose the greatest threat due to their possible deep penetration into the lungs of living organisms or potentially even the bloodstream [8-10]. These adverse health effects depend not only on the level of PM concentration in the air but also on its particular internal composition [11].

Fire effluents are not the sole potential environmental hazard. Since water is by far the most common fire suppressant used by fire services for structure fires, firefighting water runoff presents a major potential threat to the aquatic environment from fires in the short term. Along with significant water solubility of fire-generated toxic substances, fire retardants, foam suppressants and other firefighting agents were shown to be harmful to aquatic organisms [12]. The European Environmental Agency report has openly stated that the ecological impact of industrial firefighting activities, which can contaminate surface- and groundwater, is more severe than the impact of smoke from fires [13]. Until now, little research has been done on ecotoxicity of fire effluents in comparison with human toxicity studies, 
mainly due to complex issues related to pathways of fire-to-air transfer mechanisms and subsequent deposition in soil or water or uptake by organisms. These mechanisms are generally studied by theoretical methods or with case studies and field measurements [14-16]. Furthermore, challenges also exist in identifying and appropriately sampling toxic substances during and after a fire event. Since the extent of toxicity and environmental contamination is largely dependent on the fire conditions, the fuel, the surrounding environment, duration of burning, transmission and susceptibility of the receptor, it is also necessary to improve our understanding of the nature of fire. For example, the complexity of toxicity assessment can be demonstrated as follows: polychlorinated dibenzodioxins and furans (PCDD/Fs) are powerful carcinogenic compounds generated in fires with chlorinecontaining fuel (e.g. PVC). In wildland fires, the main fuel is biomass with generally low chlorine content, resulting in fairly low PCDD/F concentrations, with PAHs being the main ecotoxic concern per mass unit of burned biomass. In residential or industrial fires, on the other hand, significantly higher quantities of chlorine-containing fuel might be available, leading to significantly higher concentrations (or even total amounts) of PCDD/Fs being produced per mass unit of fuel, even with comparatively smaller fire sizes [17-19]. Care must be taken, however, given the large volume of fuel that can be involved during wildland fires; an accumulation of these events could be a significant source of PCDD/Fs, particularly during years with extensive forest fires. Therefore, targeted experiments to establish a relationship between the controlled conditions and fire effluents production are needed to improve this understanding.

Bench-scale tests could be a useful tool for ecotoxicity tests. Bench-scale fire property measuring methods are designed for single, unique combustion conditions in a controlled laboratory environment. In this way, individual fire stages or combustion conditions can be reproduced to obtain the organic and inorganic composition of fire effluents for a specific situation or scenario of fire. Furthermore, toxicants and pollutants can be captured and manually introduced to different test environments (water, sediments, soil, dilution in air) on a lab-scale, making it possible to observe (bio)chemical changes within and their influence on targeted organisms.

In this review article, we focused on possible approaches to assess the environmental impact of toxic compounds emitted by fire effluents. Toxic substances have a strong influence on ecosystems and organisms. Whereas toxicology usually deals with the effects of toxic substances on individuals, ecotoxicology emphasizes populations. Consequently, interactions between ecology and toxicology are very important. These interactions may be complex and may involve food chains and several different organizational levels, which increases the importance of following organic and inorganic toxicants through these levels. The first level is the composition during emission of the toxicants; the second level is when the toxicant or pollutant is introduced into the environmental system, which may result in structural changes of the toxicant and biochemical changes inside organisms. On the third level, physiological alterations in organisms and population changes should be investigated. As more data on fires and impacts become available, such an approach to assessing aggregated impacts can be developed. In the last years, 
more research groups start to acknowledge the importance of the effect of firefighting on the environment. Martin et al. [20] already discussed the impact of fire effluents in an interesting review article. Their main focus was the different methodologies for analysing the impacts of fires (life cycle analysis, cost-benefit analysis, risk assessment, decision making tools), while the main gaps and opportunities for future research were also discussed. Also the international organization for standardization (ISO) Technical Committee TC 92, which addresses fire safety concerns, has a workgroup focusing on fire threats to the environment (ISO/TC 92/SC3/WP6). In this frame, ISO-standards were published with guidelines on the assessment of the adverse environmental impact of fire effluents [21, 22].

\section{Bench-Scale Tests as a Method to Determine the Fire Effluent Toxicity}

Although each fire may be regarded as unique, burning behaviour and toxic product yields depend most strongly on a few factors. Material composition, temperature and oxygen availability are normally the most important [1]. Therefore, a bench-scale method must be capable of replicating large-scale fires in the sense of reproducing individual fire stages or combustion conditions. From the obtained data, models of combustion toxicity can be prepared, and indirectly, ecotoxicity studies can be performed by introducing captured fire effluents to test environments on lab-scale. With appropriate input data, these results can be also used to make (eco)toxicity assessments for potential large-scale fires or for investigation of specific incidents. However, a constant challenge remains to establish an adequate way of conducting bench-scale tests and properly interpret the obtained data in a way that their relevance is kept to full-scale tests [23].

When conducting bench-scale tests, there are several aspects that have to be taken into account [23-25]:

- Full-scale fires simultaneously involve distinct fire stages in separate places, interlinked with chemical and thermal feedbacks.

- Combustion conditions can also change during the bench-scale test, with each condition having an unknown duration. Therefore, it is hard to correlate the results of such a test to a single, unique, controlled condition.

- The behaviour of fire may change on scale-up.

- The yield and nature of the fire effluents are a function of the fuels involved and the fire conditions. These conditions affect the burning rate and degree of oxidation of the effluent. A developed fire burns at the rate dependent on the ventilation. To obtain data to model or predict such fires, it is necessary to understand the relationship between the ventilation condition and the toxic product yields.

- One of the objectives of bench-scale testing is obtaining fundamental characteristics of materials. Unfortunately, there is not yet a methodology that can correlate the material properties with a certain fire behaviour, enabling to predict its 
toxicity. This is true even for homogeneous materials, and the problems are intensified for inhomogeneous ones.

- Bench-scale toxicity tests cannot be fully and adequately specified without knowing the real-scale fire types that they are to represent (scenario). When the real-scale fire characteristics are known, an attempt should be made to match conditions in the bench-scale test.

\subsection{Thermal Environment of the Test Specimen}

In order to assess the validity of a particular bench-scale fire model, it is necessary to consider the parameters affecting the burning behaviour at each fire stage and the yields of toxic products that are replicated by the model. The temperature profile around a product undergoing combustion determines both the burning rate and the yields of the combustion products. The nature of this profile varies with the fire type. The challenge any bench-scale apparatus has to meet is to be capable of replicating at least one of the fire stages below [1].

The combustion process is generally divided into several stages. In wildfires pyrolysis (pre-ignition), flaming combustion and smouldering (or glowing) are the main stages [26]. Compartment fires are developed via another course of events. Once smouldering is initiated, a hot glowing char is often formed, in which the carbon oxidises exothermically. When the hot char decomposes, it heats the neighbouring material, initiating a non-flaming thermal decomposition [27]. Pyrolysis occurs when a fuel is heated and chemical material transformations occur at the fuel surface. Non-flaming fires typically produce high yields of toxic products at fairly low rate. When sufficiently high temperatures are reached, flaming fires occur. Flaming combustion involves much shorter reaction times, and for small fires converts most of the fuel to carbon dioxide and water. Fires in enclosures, such as buildings, trap the hot reacting gases below the ceiling, increasing the temperature, despite the lack of oxygen, and flaming can continue at oxygen concentrations less than 5\% [28]. This is because during stable flaming, volatiles produced by the decomposing material are transported just outside the solid material into the reaction zone, with flaming combustion occurring entirely in the gas phase. Under well-ventilated conditions, mixing with cold air results in the extinguishment of the flame tip. This causes smoke particles and small amounts of partially decomposed organics to escape without being fully combusted. In ventilation-controlled flaming fires, flames are also, in part, burning in the upper, oxygen-depleted smoke layer. These processes result in inefficient, fuel-rich combustion with high yields of dense smoke and toxic chemical species. For larger fires, the flame zone is too big to allow access to sufficient oxygen so even large open-air fires are under ventilated. When flashover occurs, all fuels in the area become involved in the fire. This happens when the ventilation is sufficient to raise the upper layer temperature up to $550-600^{\circ} \mathrm{C}$, and the amount of burning fuel is sufficient for the heat radiation to pyrolyse and then ignite any fuel in the neighbourhood [29, 30]. 


\subsection{Bench-Scale Tests}

There are several ISO standard methods using bench-scale tests in the assessment of fire effluent toxicity [31-33]. The most common examples are the steady-state tube furnace (ISO TS 19700), smoke density chamber (ISO 5659-2) and cone calorimeter (ISO 5660-1) tests. The steady state tube furnace was designed specifically for the assessment of smoke toxicity. The smoke density chamber was designed to assess smoke generation to regulate for visual opacity, and the cone calorimeter was designed as a tool to investigate material flammability and burning behaviour.

The steady-state tube furnace method (ISO TS 19700) [31] allows for potential atmosphere and temperature control during the experiment, using pre-decided and controlled combustion conditions. The released gases can be analysed using appropriate techniques. However, the method is limited to fairly small linear samples, typically $25 \mathrm{~mm} \times 25 \mathrm{~mm} \times 800 \mathrm{~mm}$ or less, and it is most appropriate for testing individual materials. Testing thickly layered composite materials may not be possible with this method.

The smoke density chamber test (ISO 5659-2) [32] uses test samples that are square and flatter $(75 \mathrm{~mm}$ by $75 \mathrm{~mm}$, thickness of few tens of $\mathrm{mm}$ ). During the experiment, the sample is confined in a closed air-filled chamber. The main drawback is that after ignition, the sample burns in conditions that are not controlled but rather governed by initial conditions, the development of gases and oxygen consumption. This test also does not endeavour to represent full-scale fire performance. Therefore, interpretation of the results is key to ensure that they are not extrapolated outside of their application area.

The standard cone calorimeter method (ISO 5660-1) [33] is widely used as a flammability assessment tool. The sample burns in an open, standardised atmosphere with nominal $21 \%$ oxygen. The samples are $100 \mathrm{~mm}$ by $100 \mathrm{~mm}$, up to $50 \mathrm{~mm}$ thick, and of similar mass compared to the tube furnace method, to which the toxic gas yields in well-ventilated flaming combustion are comparable. Modifications improved the working of the basic cone calorimeter method. Adding a chamber to the experimental set-up allowed the specimen to burn with a flow- and concentration-controlled amount of available oxygen. In first variations, enclosing the whole thermal part of the apparatus was considered, while later, the controlled atmosphere chamber (CAC) was used. The CAC was improved by adding a stack to allow a longer burning time of the gases before contact with cold atmospheric air. These modifications combine the positive aspects of the standard cone calorimeter method (ISO 5660-1) and the tube furnace method (ISO TS 19700). This is a promising tool that is complementary to the tube furnace as a smallscale toxicity test. Both tests have the potential to generate interesting information that could be used in modelling. However, to date, no standard apparatus design has been accepted because the major disadvantage for studying under-ventilated flaming (heat fluxes $>50 \mathrm{~kW} \mathrm{~m}^{-2}$ ) is that the load cell becomes over-heated during the time required for the lower oxygen concentration to fill the chamber. Thus, mass losses cannot be recorded for the type of developed flaming intended. Closed chamber tests at their current state also exhibit difficulties in replicating 
fire effluents when the burning is in under-ventilated mode. It seems this is mainly due to the fact that part of the burning also takes place outside of the chamber; the relatively short stack may also be the reason for this increased variability.

The key difference between methods is that in the ISO TS 19700 test, the sample burns at a fixed rate as it is fed into a furnace of increasing heat flux, so the ventilation can be pre-set. In the cone calorimeter and smoke density chamber, the heat flux is fixed, and the burning rate of the sample is allowed to vary, so the ventilation condition cannot be controlled.

\subsection{Toxicity and Ecotoxicity Assessment with Bench-Scale Tests}

Bench-scale tests have already been proven to be a useful tool for toxicity assessments. Nonetheless, some difficulties in replicating experiments in under-ventilated conditions are indicated. For toxicity assessment, most research is based on smoke components like $\mathrm{CO}, \mathrm{CO}_{2}, \mathrm{HCl}, \mathrm{HCN}$ and $\mathrm{NO}_{\mathrm{x}}$ combined with a theoretical toxicity determination by calculating fractional effective dose (FED) and $\mathrm{LC}_{50}$ (lethal concentration of the fire effluent emitted to produce death in $50 \%$ of test animals) with simple mathematical equations (see Table 1) [1]. Amon et al. [76] evaluated the existing models and measurement methods and have written an excellent report summarising methods to develop toxicity and ecotoxicity data from different scale experiments. Investigations were performed to determine which chemical species should be included in the eco-toxicological evaluation of fires and catalogue the existing models and measurement methods that are appropriate to characterize the identified species. Information is provided about eco-toxicants produced in fire effluent, together with predictive models and measurement techniques that can be used for determining the presence and concentrations of ecotoxicants caused by a fire incident. The harmful effects of unwanted fire on the environment was described by using predictive models, physical measurements, gap analysis and life cycle analysis (LCA), which were found in the existing literature.

\section{Analytical Techniques to Detect Toxic Compounds}

Organic compounds are considered the most important products in fire effluents that can have an adverse effect on human health and the environment [1]. To assess the total hazard of an occurring fire, it is not only important to determine the initial composition of the effluent but also to investigate the possible (chemical) composition changes taking place during transport from the fire into its surroundings. If fire causes an impact to the environment, it will generally affect a large area and the ecology of that area. The impacts can be broken into pathways, over which the hazards travel from the source to the target [20]. The main pathways for environmental pollution by fires are through water, air, and soil. Since the composition of organic products, generated from fires, changes rapidly with progression of combustion, and in a manner that is dependent on the fire condition, such analyses can be challenging. First of all, it is difficult to identify all individual organic compounds and their exact concentrations produced during 


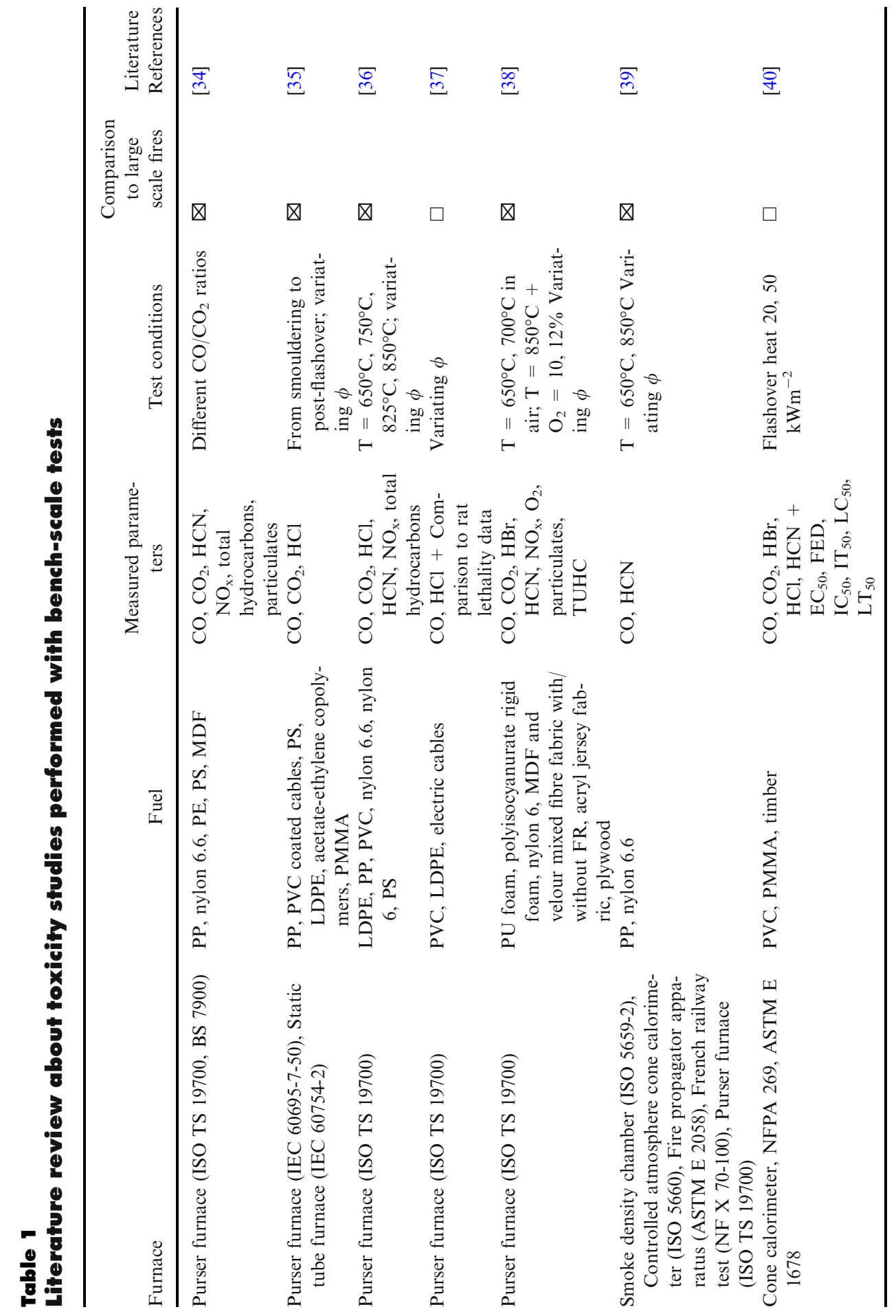


Review: The Use of Bench-Scale Tests to Determine Toxic Organic Compounds 633

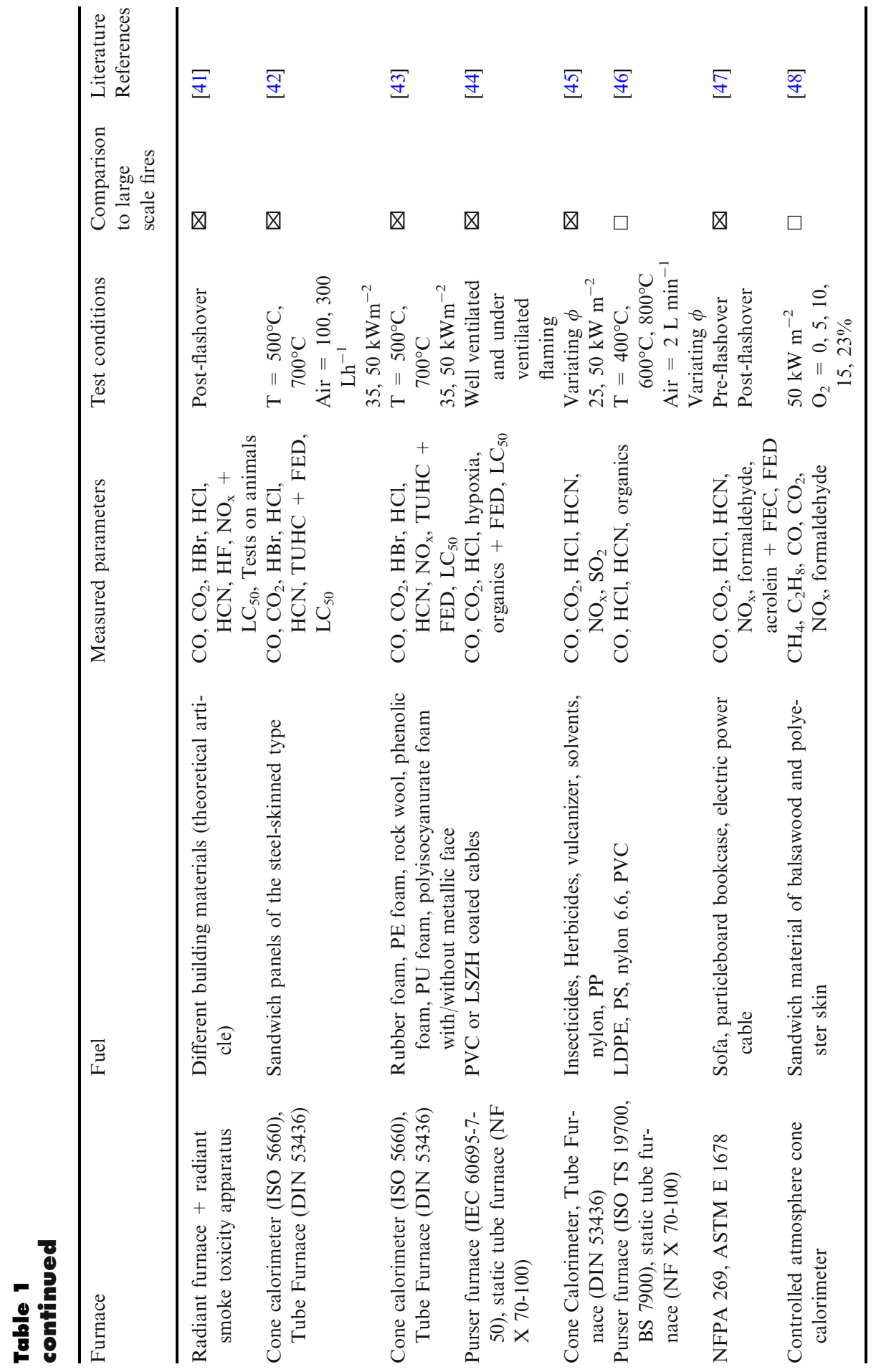




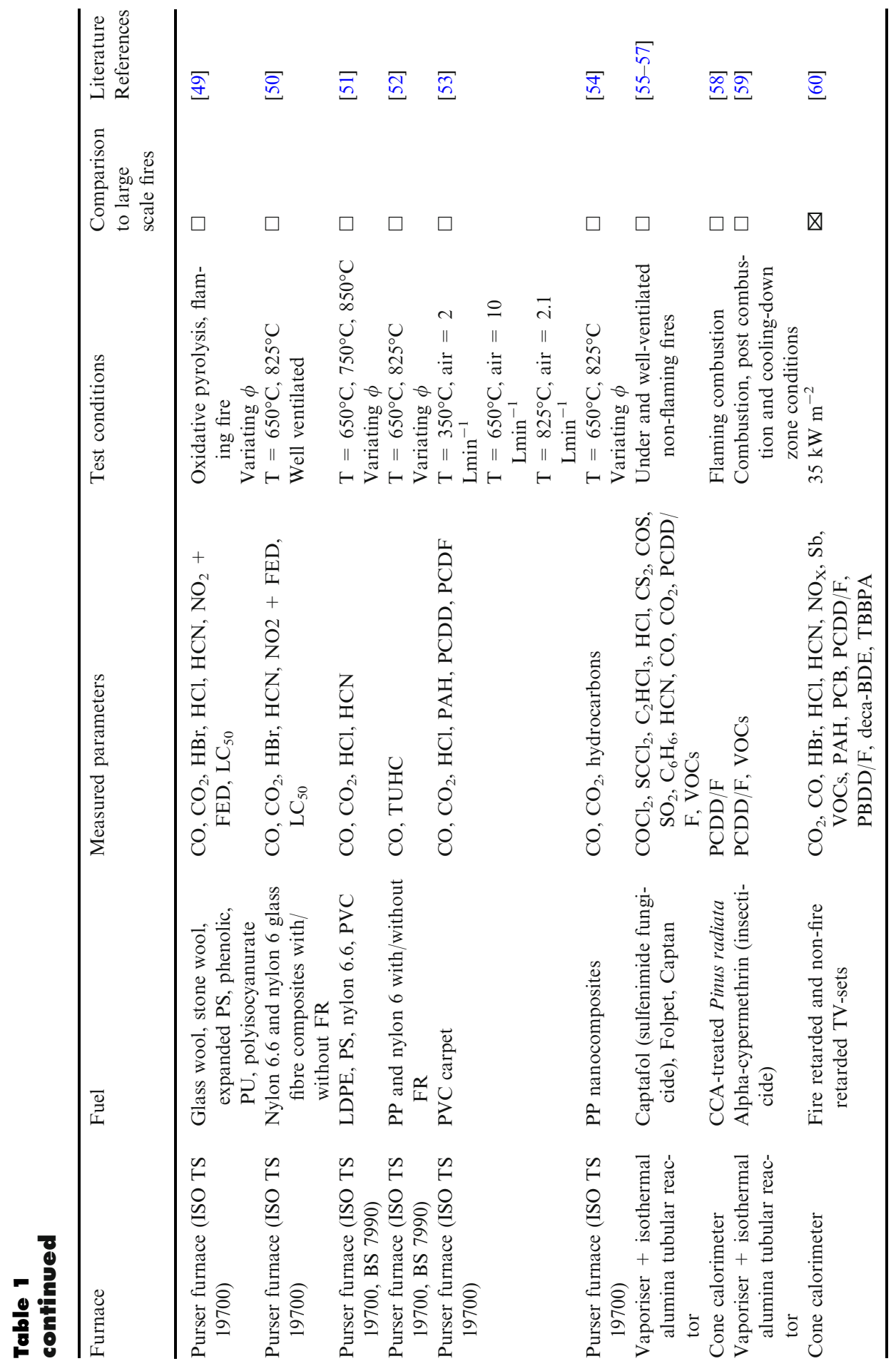


Review: The Use of Bench-Scale Tests to Determine Toxic Organic Compounds 635

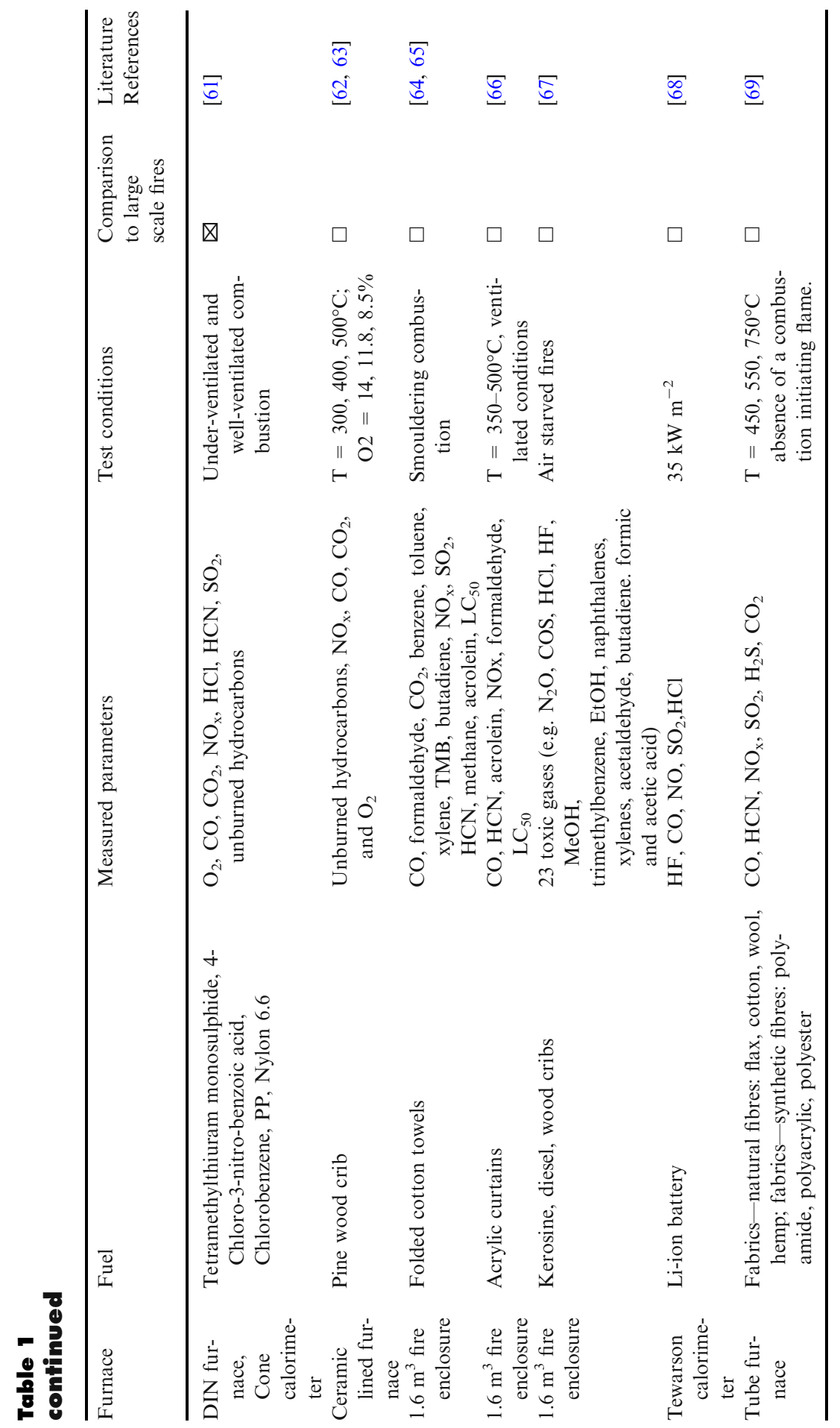




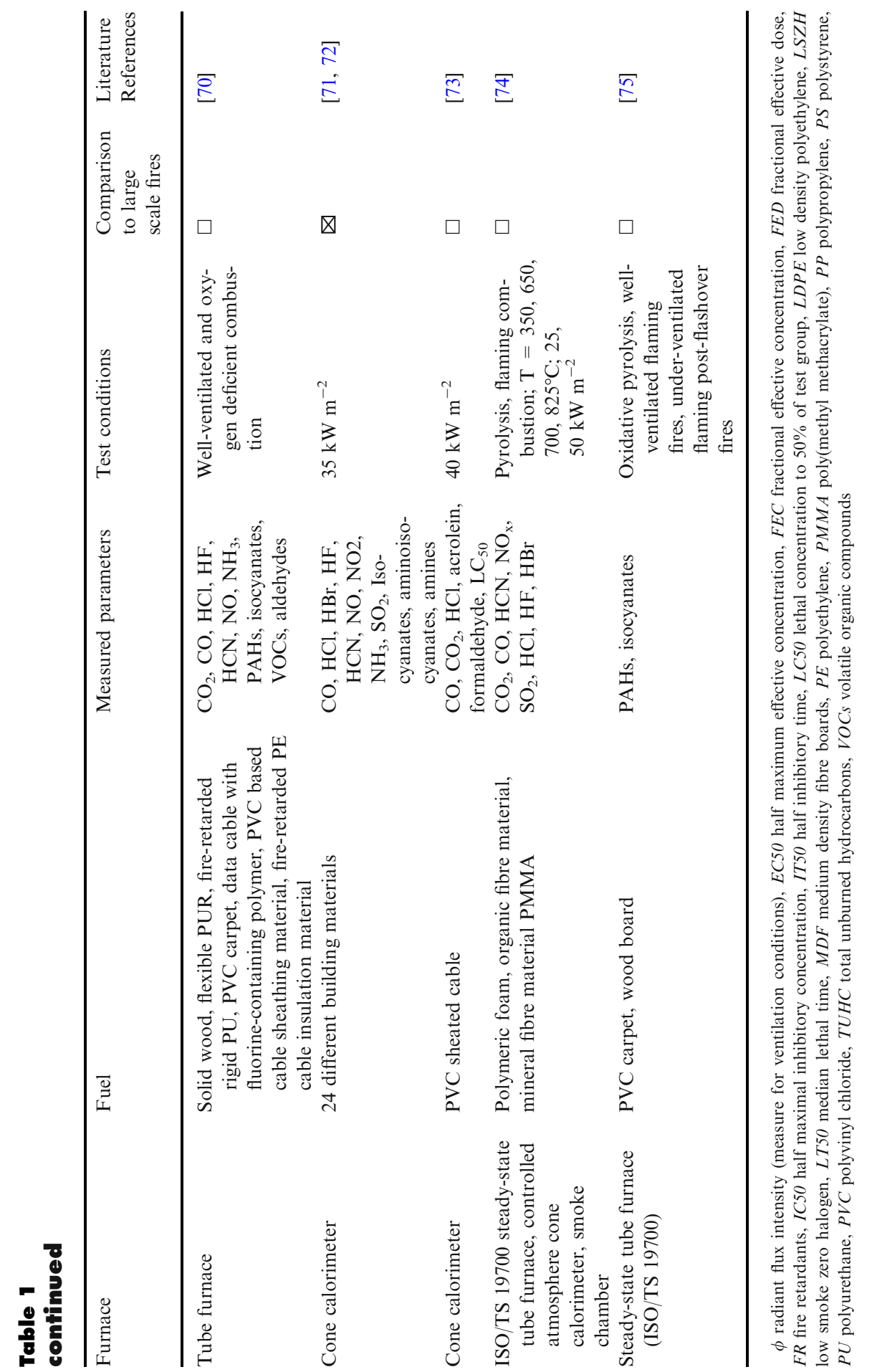


combustion. Another problem is the large variety in the structure and, as such, the solubility of created compounds, which makes a complete extraction very difficult. Furthermore, the variety of the compounds in the fire effluent extract calls for multiple analytical methods (e.g. Fourier Transformation Infrared spectroscopy [FTIR], high pressure liquid chromatography [HPLC] and gas chromatography mass spectrometry [GC-MS], the latter two with different sampling and adsorption/desorption techniques) to be employed on the same effluent sample in order to detect as many as possible. Lastly, the lack of multi-compound standards or verified chemometric methods of analysis makes the final processing of spectra and determination of present compounds difficult and prone to errors.

There are hundreds of measurement, sampling, and testing techniques for quantifying the concentration of compounds in the environment, along with many guidance documents for development of sampling/testing protocols. In this chapter, measurement techniques were collected from standards organizations, government regulations, and the literature. ISO published a document to standardize the collection and measurements in the environment of certain pollutants, which are produced during fire events [22]. Amon et al. [76] found a smart way to compile all this information into an "Eco-tox spreadsheet". The spreadsheet contains ecotoxicants, their phase, predictive models, measurement techniques, uncertainty of predictions or measurements, and the scope/limitations of use for the models and measurements.

The route by which the eco-toxicants are transported into the environment and/ or the environmental phase in which the eco-toxicant meets its fate is given. This may involve multiple phases. To evaluate the impact of persisting organic pollutants, originating from fire effluents, on the environment, analytical procedures, which are specific for the studied class of toxic components and test environments (soil, aquatic environment, air or sediments), are required. The main problem is that most techniques are not time-resolved, which means that for each time interval a new sample needs to be collected. The concentrations found in a fire-polluted environment must be compared with a corresponding unpolluted "control" and composition of the fire effluents. In this way, it is possible to estimate the extent of toxic hazard and study transformations of organic compounds during transport into or interactions with the previously present components in a particular environment.

Sampling of emissions to the air can only be made when the fire is ongoing, and sampling from the fire plume is extremely difficult. In the air, free organic compounds, as well as organics present on PM, can be determined. Analytical techniques intended to measure ecotoxicants in the aquatic environment are described better than for other environments. Those optimised for waste or drinking water can also be applied on water in rivers and lakes or run-off water obtained from fire extinguishing, but sea water is often a more complex matrix and different analytical techniques are required. Soils and sediments are by all accounts more complex matrices to differentiate between the abundant present organic matter and the contamination. This is especially valid if the contamination is only present in lower concentrations. 
Most literature for toxicity assessment is focused on the fire effluents released into the air, which can contain many corrosive, toxic, irritant or combustible chemical species together with relatively large quantities of condensable water. The standard ISO19701:2013 [77] describes how to measure $\mathrm{CO}, \mathrm{CO}_{2}, \mathrm{HCN}, \mathrm{HCl}$, $\mathrm{HBr}, \mathrm{HF}$, NOx, acrolein, formaldehyde, acetaldehyde, $\mathrm{SO}_{2}, \mathrm{CS}_{2}$, ammonia, heavy metals, phosphates, phenol, benzene, toluene, styrene, nitriles, formic acids, isocyanates and total hydrocarbons with Colorimetry, HPLC, GC-MS and inductive coupled plasma (ICP) as the main analytical tools. However, for some of these gases, FTIR spectroscopy offers an improved procedure because it provides 'insitu' time-resolved measurements over relatively short periods. FTIR analysis of fire gases is now conducted routinely in tests in labs all over the world. Quantitative analysis of inorganic and selected smaller organic species is conducted with high precision following ISO19702:2015 [78]. The analysis of bigger organic species is, however, more challenging due to the complex fire gas mixture.

In addition to the compounds mentioned above, hundreds of different volatile organic compounds (VOCs) are also released during fires. Sampling and analysis of nonpolar VOCs is described in the U.S. Environmental Protection Agency (EPA) TO14A method [79]. Other frequently used methods for collecting VOCs are solid phase micro extraction (SPME), syringe, sorption tubes, midget impingers and Tedlar bags [80]. Several groups did a thorough study about a multitude of possible VOCs that can be released during different types of fires [81-85]. Care must be taken because VOCs can be released as free pollutants into the air or adsorbed on PM; therefore, different measurement techniques are necessary [8688].

Carcinogenic compounds like polychlorinated biphenyls (PCBs), dioxins and PAHs are also found both as volatiles as well as adsorbed to PM in fire effluents and air. There exist several methods for capturing these compounds, mainly using XAD adsorbents and polyurethane foams (PUFs) in combination with glass-fibre or quartz filters. The standardised method for sampling of PCDD/Fs in fire effluents via the filter/condenser method is described in EN1948:1-3:1997 [89]. GC-MS is the main method for their qualification and quantification, while PAHs, if in high enough concentrations, can be analysed using HPLC. Analysis of PCDD/Fs is standardized in EPA method 23 [90], while the procedure for PCDD/Fs on PM10 or fly ash is found in RCRA method 8280 [91] and EPA Method 201a/202 [92, 93]. The EPA TO-13A [94] for sampling and analysis methods of PAHs in ambient air could be perfectly applied for determining PAHs in fire effluents and air. There have also been several reports on the determination of PAHs [95-106], PCDD/Fs [95-97, 107-111], organic pollutants [112, 113] and PCBs [95-97] in fire effluents and air following non-standardised methods or modifications of the existing standards.

Also, a whole range of unknown organic and inorganic compounds can be adsorbed on PM in addition to PCBs, dioxins and PAHs. Methods to extract and analyse PM captured on various filters have been developed by Fine et al., Garcia-Hurtado and Hays et al. [86, 114, 115].

Afterwards, these gaseous organic pollutants, which are formed in the fire plume and adsorbed onto a particle, can drop out of the atmosphere and deposit 
on the surface of a stream or on the soil, thereby polluting nearby surface water, soil or sediment. Another way of releasing eco-toxicants into the nearby environment is via water run-off produced from fire extinguishing agents. Several studies were performed to measure ecotoxicants inside the environment. Procedures to measure PAH concentration are described for surface water [116-118], sea water [104], soil [119] or sediments [118, 120, 121]. Methods to measure the PCDD/F concentration found in water and on the PM present in water [122-124], soils [125] and sediments [125] are also described. Procedures on how to measure VOCs are described for surface water [87, 126, 127], soils [128-130] and sediments [128]. General organic pollutants can be determined in surface water [131, 132], soils [133] and sediments [133].

\section{4. (Eco)toxicological Assessment}

In this section, the different existing approaches to estimate fire effluent toxicity on humans and their direct effects of exposure on the environment will be considered, in light of their advantages and/or disadvantages. Ultimately, it is of interest to investigate how environmental impacts of fire might aggregate: locally, regionally and globally. As more data on fires and impacts become available, such an approach to assessing aggregated impacts can be developed.

\subsection{Toxicology of Fire Effluent Gasses}

There is a lack of knowledge on the effect of organic products in fire effluents on the human body since it cannot be measured directly for legal and ethical reasons. Different human toxicity assessment methods were established to overcome this type of problem. In vitro studies use human cells, isolated tissues and organs outside the body to investigate the toxic and adverse reactions of substances towards them $[1,134]$. These types of experiments have potential to replace animal testing [134]. Tests on animals are performed either directly, using animal exposure, or indirectly, by comparing the measured toxins' concentrations in a particular medium with information on dose-dependent effect recorded in one or several previous studies. Animal testing is not a preferred system of use since it has certain shortcomings. The data rely on the untested assumption that effects on animal subjects may be simply extrapolated to humans [135]. Sadly, there is a lack of procedures to be used to evaluate the lethal concentration limits and the lethal dose for a broad range of organic compounds.

The general approach in generating toxic potency data from chemical analysis is to assume additive behaviour of individual toxic compound and express each concentration as a fraction of the lethal concentration for $50 \%$ of the population for a 30-min exposure $\left(\mathrm{LC}_{50}\right)$. Summing these contributions generates a fractional effective dose (FED) [136]. The use of this additive model is almost certainly an over-simplification because the toxic effects of different gases occur in different organs [25]. 
The most appropriate way to determine the toxicity of fires in buildings is described in ISO 13571 [137], which predicts the incapacitation for humans exposed to fire smoke. This standard is based largely on primate exposure data.

\subsection{Ecotoxicity Tests on the Nearby Environment, Contaminated by Fire Effluents or Fire Supressing Agents}

Ecotoxicity is the study of how chemicals interact with organisms in the environment. Assessments of ecotoxicological effects include estimating the amount of bioaccumulation of a chemical within the food web and its persistence in the environment. These two factors affect the amount and duration of environmental exposure and help predict which organisms are most likely to be affected [138]. For this purpose, it is of extreme importance that reports of environmental contamination following major fire disasters are prepared [20, 139-141]. Such data are usually not collected due to a combination of factors: emergency services are too busy dealing with the fire to monitor the emissions, they lack necessary training to monitor emissions or to understand the impacts of firefighting on the environment. In some countries, there are other public servants that could be called to the scene of a fire to take responsibility for emissions measurements, but they are not always informed when a fire occurs.

Another way of assessing ecotoxicity is by exposure studies on organisms. Primary measurement end points for acute and chronic toxicity are organisms' survival, growth and, often, reproduction. Aquatic bioassays include water column (Daphnia, crustaceans, algae and fish-freshwater and marine), sediment (Chironomus, Hyalella, oyster) and amphibians (frog embryos). Terrestrial assays include standardized studies for germination and growth of plants (e.g. Trifolium sp.), various types of soft- and hard-bodied soil invertebrates, honeybees and birds. Soil microbial function tests are also available to determine chemical effects on respiration, decomposition and nitrogen fixation. In general, the information for toxicity to terrestrial organisms is also sparse. [129].

Avoidance response was introduced as an easy, fast and sensitive ecotoxicity test. For certain chemicals, the avoidance response could give results, which can be as sensitive as the ones obtained from reproduction tests; while for other chemicals, the results are at least as sensitive as the ones obtained by survival tests. The main advantage of avoidance tests is their relative short duration (maximum 2 days) and experimental simplicity (no specific life cycles of the animals required, easier counting, etc.). Standard avoidance test guidelines have been developed for earthworms [142] and Collembola (ISO 17512-2) [143], while similar tests have also been executed with enchytraeids [144-146], oribatid mites [147] and isopods [148, 149]. It was demonstrated that the avoidance behaviour is primarily determined by pollutants and not by chemical-physical soil properties. Avoidance behaviour of at least $80 \%$ of the specimens under assessment is proposed as a criterion for toxicity. Presumably such tests are limited to molecules that occur naturally, so that a detection and avoidance response has been allowed to evolve. Similar tests also exist in the aqueous environment, called the fish avoidance test [150]. 
For waters in natural environments, the Microtox ${ }^{\circledR}$ Toxicity Test is used to evaluate the inhibition of the luminescence in the marine bacterium Vibrio fischeri. In the presence of pollutant agents, the natural bioluminescence of $V$. fischeri is reduced, and the toxicity is expressed as the half maximal effective concentration (EC50) counted according to the standard procedure ISO 11348 [151]. Toxicity testing based on microorganisms is gaining popularity because it is relatively quick, reproducible, cheap and does not raise ethical issues.

Different authors have noted the influence of fire or fire extinguishing agents on the environment. Meharg et al. [5] investigated a forest ecosystem, which was contaminated as a result of a fire involving 600t of PVC. Forests effectively scrub semi-volatiles from the atmosphere, leading to elevated levels of detected contaminants in forests compared to non-forested areas. Livers of wood mice (Apodemus sylvaticus) caught in these areas were analysed for dioxins and furans, showing elevated residues and physiological damage in the rodents.

McDonald et al. [12] conducted acute toxicity tests of firefighting chemicals and foam-like fire suppressants on important aquatic invertebrates, such as the amphipod $H$. azteca, since disruption of ecosystem functions at lower trophic levels could, in turn, impair the health and well-being of organisms at higher trophic levels, such as fish.

Silva et al. [4] studied the deleterious effects of the ash-laden runoff from forest fires on water quality by preparing aqueous extracts of this ash (AEA). The AEA was analysed with respect to a large group of chemical compounds and the sixteen prioritized PAHs. An ecotoxicological screening of the AEA was performed with four standard aquatic species from different functional groups and trophic levels with limited results.

Hertzberg et al. [152] investigated the influence of $\mathrm{HCl}$ and $\mathrm{PVC}$-smoke by a new method involving isolated and perfused guinea pig lungs. A rapid decline in the lung physiology parameters, conductance and compliance was observed. Additionally, PM was found at different levels in the lung tissues and chemical species from the smoke gases were found in the artificial blood solution in the lungs used in the experiments.

To ensure environmental safety of fire extinguishing chemicals used to fight forest fires, the U.S. Forest Service requested an investigation to determine the potential for UV-enhanced toxicity and environmental persistence of fire-retardant chemicals [153, 154]. Their results showed persistent toxicity of rainwater runoff, particularly from sandy or rocky surfaces, while soils high in organic matter rapidly decreased chemical persistence. Other fire-related factors, such as ash effluents, may increase the chemical toxicity of rainwater runoff.

\section{The Importance of Material Toxicity Studies and Fire LCA Analysis}

Materials used in buildings are generally considered for their properties from several perspectives, such as mechanical and aesthetical characteristics, durability, VOC emissions, and surface properties. From the point of view of toxicity and 
ecotoxicity, it is also essential to make buildings and construction products from materials that emit as little toxic compounds as possible during fires. Therefore, it is important that the toxicity of fire effluent emissions and resulting ecotoxicity of different materials is compared. No data exist about the impact of construction materials on the ecotoxicity, but in the literature, building materials were compared according to their fire effluent toxicity. The use of bench-scale tests, in particular with the ISO TS19700 steady state tube furnace, is, despite its shortcomings, currently the most suitable tool to perform toxicity assessments. As the toxic products of some materials vary as a function of ventilation conditions, it is necessary to perform assessments of fire toxicity under less-ventilated conditions, under which usually the most toxic effluents are emitted. Lack of studies done in all ventilation conditions, inconsistencies and shortcomings in the methodology, and lack of information about the conditions in a large building fire, make it difficult to extrapolate measured toxicities to real fire conditions. Care must be taken during fire toxicity studies because, in most cases, the bulk of the early stage fire hazard comes from combustion of occupant goods, not construction materials [155]. Therefore, toxicity studies should also focus on these types of materials.

The large amount of studies, which investigate the toxicity of polymers (see Table 1, [156]), can give valuable information on which construction materials, such as insulation foams, cable insulations or plastics, to use in buildings. However, making such decisions is not always straightforward since the toxicity of materials generally changes according to the fire scenario. It was found that since neither glass nor stone wool undergo flaming combustion, their fire toxicity is negligible compared to that from any of the foam products (e.g. expanded polystyrene, phenolic, polyurethane, polyisocyanurate) [49]. The fire toxicity of expanded polystyrene foam is lower than that of polyurethane, polyisocyanurate or even phenolic foam [49]. Hull et al. [46] found that Nylon 6.6 produces high concentrations of $\mathrm{HCN}$ in under-ventilated conditions, which makes it the most toxic plastic in such fires. PVC also shows very high levels of toxicity due to its $\mathrm{HCl}$ release in the fire effluent. Polyethylene shows high toxicity for smouldering and under-ventilated combustion but lower toxicity for well-ventilated combustion. The outcome of such toxicity studies can have major impacts. The results of the investigation of Hull et al. [41] about the fire toxicity of burned cables was used to persuade the regulators of the need to introduce a special classification in the Construction Products Regulation (305/2011/EU_CPR, 2011), which came into force across Europe in 2013. This has driven the switchover from toxic PVC to low smoke/zero halogen cable insulation coatings in the non-domestic sector over the last years.

Different researchers also studied the toxicity of fire effluents when natural wood and wood treated with preservatives or fire retardants were used as a building material. This is especially relevant as using wood in construction is becoming more and more popular because of its environmental friendliness (especially when compared with most other construction materials). It is well known that in the presence of halogens $\mathrm{PCDD} / \mathrm{F}$ are formed during wood combustion via precursors like phenols and lignin or via de novo reactions in the presence of particulate car- 
bon and chlorine, albeit in smaller amounts than from most other materials. It was found that combustion of the natural, uncontaminated wood leads to much lower PCDD/F emissions than of treated wood [157, 158]. An interesting review of dioxins during wood combustion was written by Lavric et al. [159] Test results about the behaviour of copper, chromium and arsenic in fire effluents of copperchromium arsenate (CCA)-treated wood (CCA was a widely used wood preservative in the middle of the twentieth century) showed that almost all the original amounts of chromium and copper were retained in the ash, while some of the arsenic evolved into the gas phase. This phenomenon increased with increasing temperature and air supply [160]. Otherwise, the field of wood combustion is still quite unexplored. Experiments are necessary to make comparisons between different types of wood, different combustion conditions and different experimental parameters. The ultimate goal must be an accurate and reliable determination of the specific hazard posed by different wood species and wood products that are used commercially. Another area that needs further work is that of emission toxicity from burning wood treated with preservatives and/or fire retardants. There is extensive literature concerning fire retardants per se [161, 162], but very little has been reported concerning the toxicity of emissions from wood treated with fire retardants [163].

Fire retardants also tend to have unintended negative effects on the environment and human health. Less toxic alternatives appear to be available already and manufacturers of flame retardants addressed data gaps and commissioned necessary tests and studies. Studies on the influence of fire retardants on fire toxicity showed that brominated and antimony-containing flame retardants increase the yields of the two biggest killers in fires ( $\mathrm{CO}$ and $\mathrm{HCN}$ ) [50]. It was found that it would be a significant fire safety advantage to replace brominated flame retardants. Most phosphorus, inorganic and nitrogen containing flame retardants have a low environmental impact relative to halogenated and antimony-containing flame retardants, which means that they pose less harm to the environment and do not bio-accumulate in biota [164]. In addition, they have a low (eco) toxicity profile and will eventually mineralize in nature.

Research that investigates the combustion products of several materials is of high importance. The more detailed information from each material about the released toxic products is available, the better the picture on environmental level can be made, when combining all the data from several fire types and conditions. A great example of such research can be found in the work of Blomqvist et al. [15].

Some research groups went a step further than just comparing the toxicity and environmental impact of building materials during fires by studying emissions upon combustion and took into account the whole life cycle of these products. A standard LCA model represents the best modern method to determine the environmental impact of a series of choices concerning the life cycle of any given product, from exploitation of resources to manufacturing, through use to recycling, re-utilisation or disposal. Assuming that a certain number of fire accidents are unavoidable in any society, it is important to take fires into consideration when defining the environmental impacts from products. Therefore, a Fire-LCA model 
was developed by SP in Sweden [165-167]. Such a model includes modules to account for accidents, like fires, but also recognizes the extent of the damaged area, the fire-fighting efforts and the replacement of damaged materials. The model itself is generally applicable, if appropriate additions and changes are made for each new studied case. The guidelines are better developed for items usually found as equipment, appliances, fixtures, fittings or decor in a building, although this does not exclude their application to building materials. In a first case study, a TV with high fire performance enclosure material was compared to that with easily ignitable enclosure material $[165,168-170]$. The second application of the Fire-LCA model focussed on a comparison between two types of electrical cables, assumed to have essentially the same fire performance [171, 172]. The third application of the Fire-LCA model has focussed on a comparison between two types of furniture, one having the minimal fire performance required on mainland Europe and the other with fire performance similar to that required in the UK [173, 174]. In all cases, the benefits of a higher fire performance are weighed against the "price" society has to pay for the production and handling of possible additives and/or other ways of production. The Fire-LCA model was later also applied by other research groups [175] or used as a basis to develop other assessment tools [176]. Another type of model is the Dynamic LCAFire and was developed by Chettouh et al. [177].

The most important aspect is that LCA-based environmental impact methods can be used to assess a wide range of environmental impact categories such as: global warming, eutrophication, resource depletion, ecotoxicity of soil and water bodies.

\section{Conclusions}

Ecotoxicity studies are a fascinating multidisciplinary area, investigating how fuel chemistry, conditions of complex fire processes and the effect and dynamics of produced fire effluents can have a significant influence on ecosystems. It requires understanding the stages of fire growth from ignition to ventilation-controlled burning, the behaviour of fire on different scales, the behaviour of aerosol particulates and chemical components in different environments, the response of living organisms to the components present as well as their chemical quantification and their relationship to its ecotoxicity.

Nonetheless, the current state of research in the field of fire ecotoxicity leaves a lot to be desired. Several methods are already developed to measure concentrations of organic and inorganic products that are generated during fires. However, no functional mathematical algorithms exist yet to interpolate these measured concentrations into a valid assessment of the toxicity of a fire, resulting in the fact that there is currently no way to satisfactorily assess its environmental impact. This is mainly because we do not yet really know either the short- or long-term exposure effects of many of these chemicals, which makes it hard to judge their combined effects in varying concentrations. Additionally, these compounds are spread by smoke particles generated in the fires, and the properties of these parti- 
cles should also be taken into account. Finally, the fact that different compounds can interact with each other or with their environment, when conditions change, makes it even harder to create fitting models of their behaviour and toxicity.

Bench-scale methods, which create specific fire conditions on a lab-scale, can generate a lot of information on what is released during a real fire event, especially in controlled atmosphere environments. However, the largely incomplete data gathered so far is difficult to interpret to the level of an actual wildfire or residential/industrial fire. These types of tests are also useful to compare the fire toxicity effects of construction materials. In this way, engineers can focus on the use of the safest and most environmentally friendly materials in the construction of future houses. Until now, most of the data gathered experimentally is collected from burning only a single type of material. Therefore, one of the future challenges in fire toxicity will be to investigate materials' interaction of burning composites and determine its impact on the environment.

\section{Acknowledgements}

Authors acknowledge the European Commission for funding InnoRenew $\mathrm{CoE}$ (Grant Agreement \#739574), under the H2020 Widespread-Teaming programme, and the Republic of Slovenia (investment funding from the Republic of Slovenia and the European Union's European Regional Development Fund) as well as ARRS research Project J4-1767.

\section{Availability of Data and Material}

Not applicable.

\section{Compliance with Ethical Standards}

Conflict of inferest The researchers claim no conflicts of interest.

Code Availability Not applicable.

\section{Open Access}

This article is licensed under a Creative Commons Attribution 4.0 International License, which permits use, sharing, adaptation, distribution and reproduction in any medium or format, as long as you give appropriate credit to the original author(s) and the source, provide a link to the Creative Commons licence, and indicate if changes were made. The images or other third party material in this article are included in the article's Creative Commons licence, unless indicated otherwise in a credit line to the material. If material is not included in the article's Creative Commons licence and your intended use is not permitted by statutory 
regulation or exceeds the permitted use, you will need to obtain permission directly from the copyright holder. To view a copy of this licence, visit http://creat ivecommons.org/licenses/by/4.0/.

\section{References}

1. Hull TR (2010) Bench-scale generation of fire effluents. In: Stec A, Hull R (eds) Fire toxicity Woodhead Publishing, Cambridge, pp 424-460

2. Wakefield J (2010) HPA-CHaPD-004: a toxicological review of the products of combustion. Oxfordshire, Health Protection Agency, p. 44

3. ISO 26367-2:2017, Guidelines for assessing the adverse environmental impact of fire effluents - methodology for compiling data on environmentally significant emissions from fires, ISO, Geneva

4. Silva V, Pereira JL, Campos I et al (2015) Toxicity assessment of aqueous extracts of ash from forest fires. CATENA 135:401-408. https://doi.org/10.1016/ j.catena.2014.06.021

5. Meharg AA, Shore RF, French MC, Osborn D (1997) Dioxin and furan residues in wood mice (Apodemus sylvaticus) following a large scale polyvinyl chloride (PVC) fire. Environ Pollut 97:213-220. https://doi.org/10.1016/S0269-7491(97)00097-3

6. Ignatavièius G, Sakalauskienë G, Oškinis V (2006) Influence of land fires on increase of heavy metal concentrations in river waters of lithuania. J Environ Eng Landsc Manag 14:46-51. https://doi.org/10.1080/16486897.2006.9636878

7. Grantz D, Garner JH, Johnson D (2003) Ecological effects of particulate matter. Environ Int 29:213-239. https://doi.org/10.1016/S0160-4120(02)00181-2

8. Anderson JO, Thundiyil JG, Stolbach A (2012) Clearing the air: a review of the effects of particulate matter air pollution on human health. J Med Toxicol 8:166-175. https:// doi.org/10.1007/s13181-011-0203-1

9. Valavanidis A, Fiotakis K, Vlachogianni T (2008) Airborne particulate matter and human health: toxicological assessment and importance of size and composition of particles for oxidative damage and carcinogenic mechanisms. J Environ Sci Heal Part C 26:339-362. https://doi.org/10.1080/10590500802494538

10. Xing Y-F, Xu Y-H, Shi M-H, Lian Y-X (2016) The impact of PM2.5 on the human respiratory system. J Thorac Dis 8:E69-E74. https://doi.org/10.3978/j.issn.20721439.2016.01.19

11. Polichetti G, Cocco S, Spinali A et al (2009) Effects of particulate matter (PM10, PM2.5 and PM1) on the cardiovascular system. Toxicology 261:1-8. https://doi.org/ 10.1016/j.tox.2009.04.035

12. McDonald SF, Hamilton SJ, Buhl KJ, Heisinger JF (1997) Acute toxicity of fire-retardant and foam-suppressant chemicals to Hyalella azteca (Saussure). Environ Toxicol Chem 16:1370-1376. https://doi.org/10.1897/1551-5028(1997)016<1370:ATOFRA $>2.3 . \mathrm{CO} ; 2$

13. European Environment Agency (2010) Mapping the impacts of natural hazards and technological accidents in Europe: an overview of the last decade. European Environment Agency, Copenhagen

14. Biočanin R, Stefanov S, Urošević S, Mekić S (2012) Modeling of pollutants in the air in terms of fire on dumps. Ecol Chem Eng S 19:609-616. https://doi.org/10.2478/ v10216-011-0043-6

15. Blomqvist P, Persson B, Simonson M (2007) Fire emissions of organics into the atmosphere. Fire Technol 43:213-231. https://doi.org/10.1007/s10694-007-0011-y 
16. Chrysikou L, Gemenetzis P, Kouras A et al (2008) Distribution of persistent organic pollutants, polycyclic aromatic hydrocarbons and trace elements in soil and vegetation following a large scale landfill fire in northern Greece. Environ Int 34:210-225. https:// doi.org/10.1016/j.envint.2007.08.007

17. Hutzinger O, Choudhry GG, Chittim BG, Johnston LE (1985) Formation of polychlorinated dibenzofurans and dioxins during combustion, electrical equipment fires and PCB incineration. Environ Health Perspect 60:3-9. https://doi.org/10.1289/ehp.85603

18. Vikelsøe J, Johansen E (2000) Estimation of dioxin emission from fires in chemicals. Chemosphere 40:165-175. https://doi.org/10.1016/S0045-6535(99)00231-3

19. Kim E-J, Oh J-E, Chang Y-S (2003) Effects of forest fire on the level and distribution of PCDD/Fs and PAHs in soil. Sci Total Environ 311:177-189. https://doi.org/ 10.1016/S0048-9697(03)00095-0

20. Martin D, Tomida M, Meacham B (2016) Environmental impact of fire. Fire Sci Rev 5:21. https://doi.org/10.1186/s40038-016-0014-1

21. ISO 26367-1:2019. Guidelines for assessing the adverse environmental impact of fire effluents - part 1: general. ISO, Geneva

22. ISO 26367-2:2017. Guidelines for assessing the adverse environmental impact of fire effluents - part 2: methodology for compiling data on environmentally significant emissions from fires. ISO, Geneva

23. Nam S, De Ris J, Wu P, Bill R (2005) From bench-scale test data to predictors of full-scale fire test results. Fire Saf Sci 8:469-480. https://doi.org/10.3801/IAFSS.FSS.8469

24. Hull TR, Stec AA (2016) Chapter 5: generation, sampling and quantification of toxic combustion products. In: Purser DA, Maynard RL, Wakefield JC (eds) Toxicology, survival and health hazards of combustion products The Royal Society of Chemistry, Cambridge, pp 108-138

25. Babrauskas V, Harris RH, Braun E, et al (1991) NIST technical note 1284. The role of bench-scale test data in assessing real-scale fire toxicity, pp 120 https://doi.org/10.60 28/nist.tn. 1284

26. Byram GM (1959) Combustion of forest fuels. In: Davis KP (ed) Forest fire: control and use Mc Graw-Hill, New York, pp 61-89

27. Purser DA (2016) Chapter 2: fire types and combustion products. In: Purser DA, Maynard RL, Wakefield JC (eds) Toxicology, survival and health hazards of combustion products The Royal Society of Chemistry, Cambridge, pp 11-52

28. Morehart JH, Zukoski EE, Kubota T (1991) Characteristics of large diffusion flames burning in a vitiated atmosphere. Fire Saf Sci 3:575-583. https://doi.org/10.3801/ IAFSS.FSS.3-575

29. Gray BF (2016) Spontaneous combustion and self-heating. In: Hurley MJ, Gottuk DT, Hall JR Jr, Harada K, Kuligowski ED, Puchovsky M, Torero JL, Watts JM Jr, Wieczorek CJ (eds) SFPE handbook of fire protection engineering Springer, New York, pp 604-632

30. Drysdale D (2011) An introduction to fire dynamics. Wiley, West Sussex, p. 574

31. ISO/TS 19700:2016, Controlled equivalence ratio method for the determination of hazardous components of fire effluents. Steady-state tube furnace, ISO, Geneva

32. ISO 5659-2:2012, Plastics: smoke generation - part 2: determination of optical density by a single-chamber test, ISO, Geneva

33. ISO 5660-1:2015, Reaction-to-fire tests: heat release, smoke production and mass loss rate-part 1: heat release rate (cone calorimeter method) and smoke production rate (dynamic measurement), ISO, Geneva 
34. Stec AA, Hull TR, Purser JA, Purser DA (2009) Comparison of toxic product yields from bench-scale to ISO room. Fire Saf J 44:62-70. https://doi.org/10.1016/j.firesaf.2008.03.005

35. Hull TR, Lebek K, Paul KT (2005) Correlation of toxic product yields from tube furnace tests and large scale fires. Fire Saf Sci 8:1059-1070. https://doi.org/10.3801/ IAFSS.FSS.8-1059

36. Stec AA, Hull TR, Purser JA, Blomqvist P, Lebek K (2008) A comparison of toxic product yields obtained from five laboratories using the steady state tube furnace (ISO TS 19700). Fire Saf Sci 9:653-664. https://doi.org/10.3801/IAFSS.FSS.9-653

37. Hull TR, Stec AA, Paul KT (2008) Hydrogen chloride in fires. Fire Saf Sci 9:665-676. https://doi.org/10.3801/IAFSS.FSS.9-665

38. Purser DA, Purser JA (2008) HCN yields and fate of fuel nitrogen for materials under different combustion conditions in the ISO 19700 tube furnace and large scale fires. Fire Saf Sci 9:1117-1128. https://doi.org/10.3801/IAFSS.FSS.9-1117

39. Stec AA, Hull TR, Purser DA, Purser JA (2014) Fire toxicity assessment: comparison of asphyxiant yields from laboratory and large scale flaming fires. Fire Saf Sci 11:404 418. https://doi.org/10.3801/IAFSS.FSS.11-404

40. Chow CL, Chow WK, Lu ZA (2004) Assessment of smoke toxicity of building materials. In: Proceedings of the 6th Asia-Oceania symposium on fire science \& technology, Daegu, Korea, pp 17-20

41. Levin BC (1992) The development of a new small-scale smoke toxicity test method and its comparison with real-scale fire tests. Toxicol Lett 64(65):257-264. https:// doi.org/10.1016/0378-4274(92)90197-R

42. Babrauskas V (1997) Sandwich panel performance in full-scale and bench-scale fire tests. Fire Mater 21:53-65. https://doi.org/10.1002/(SICI)10991018(199703)21:2<53::AID-FAM593>3.0.CO;2-8

43. Babrauskas V (2000) Fire safety improvements in the combustion toxicity area: is there a role for $\mathrm{LC}_{50}$ tests?. Fire Mater 24:113-119. https://doi.org/10.1002/10991018(200003/04)24:23.0.CO;2-L

44. Hull TR, Lebek K, Pezzani M, Messa S (2008) Comparison of toxic product yields of burning cables in bench and large-scale experiments. Fire Saf J 43:140-150. https:// doi.org/10.1016/j.firesaf.2007.06.004

45. Hietaniemi J, Kallonen R, Mikkola E (1999) Burning characteristics of selected substances: production of heat, smoke and chemical species. Fire Mater 23:171-185. https://doi.org/10.1002/(SICI)1099-1018(199907/08)23:4<171::AIDFAM680 > 3.0.CO;2-C

46. Hull TR, Stec AA, Lebek K, Price D (2007) Factors affecting the combustion toxicity of polymeric materials. Polym Degrad Stab 92:2239-2246. https://doi.org/10.1016/ J.POLYMDEGRADSTAB.2007.03.032

47. Marsch ND, Gann RG, Averill JD, Nyden MR (2013) Smoke component yields from bench-scale fire tests: 1. NFPA 269/ASTM E 1678. NIST technical note 1760, p 64

48. Marquis DM, Guillaume E, Camillo A, Pavageau M, Rogaume T (2011) 12th international conference fire and materials, UK, p 12

49. Stec AA, Hull TR (2011) Assessment of the fire toxicity of building insulation materials. Energy Build 43:498-506. https://doi.org/10.1016/J.ENBUILD.2010.10.015

50. Molyneux S, Stec AA, Hull TR (2014) The effect of gas phase flame retardants on fire effluent toxicity. Polym Degrad Stab 106:36-46. https://doi.org/10.1016/j.polymdegradstab.2013.09.013 
51. Stec AA, Hull TR, Lebek K, Purser JA, Purser DA (2008) The effect of temperature and ventilation condition on the toxic product yields from burning polymers. Fire Mater 32:49-60. https://doi.org/10.1002/fam.955

52. Stec AA, Rhodes J (2011) Smoke and hydrocarbon yields form fire retarded polymer nanocomposites. Polym Degrad Stab 96:295-300. https://doi.org/10.1016/j.polymdegradstab.2010.03.032

53. Stec AA, Readman J, Blomqvist P, Gylestam D, Karlsson D, Wojtalewicz D, Dlugogorski BZ (2013) Analysis of toxic effluents released from PVC carpet under different fire conditions. Chemosphere 90:65-71. https://doi.org/10.1016/ j.chemosphere.2012.07.037

54. Zhang Q, Zhan J, Zhou K, Lu H, Zeng W, Stec AA, Hull TR, Hu Y, Gui Z (2015) The influence of carbon nanotubes on the combustion toxicity of $\mathrm{PP} /$ intumescent flame retardant composites. Polym Degrad Stab 115:38-44. https://doi.org/10.1016/ j.polymdegradstab.2015.02.010

55. Chen K, Wojtalewicz DA, Mackie JC, Kennedy EM, Dlugogorski BZ (2011) Toxicants formed in fires of captafol pesticide. Fire Saf Sci 10:227-238. https://doi.org/ 10.3801/iafss.fss.10-227

56. Chen K, Mackie JC, Kennedy EM, Dlugogorski BZ (2010) Thermal decomposition of captan and formation pathways of toxic air pollutnts. Environ Sci Technol 44:41494154. https://doi.org/10.1021/es9037935

57. Chen K, Mackie JC, Kennedy EM, Dlugogorski BZ (2011) Air pollutants formed in thermal decomposition of folpet fungicide under oxidative conditions. Environ Sci Technol 45:554-560. https://doi.org/10.1021/es102652w

58. Tame N, Kennedy EM, Dlugogorski BZ (2005) Formation of dioxin during smoldering of CCA treated wood char. Fire Saf Sci 8:1023-1033. https://doi.org/10.3801/ IAFSS.FSS.8-1023

59. Summoogum S, Wojtalewicz D, Mackie JC, Kennedy EM, Dlugogorski BZ (2011) formation of polychlorinated dibenzo-p-dioxins and polychlorinated dibenzofurans and their precursors in fires of pyrethroid pesticide alpha-cypermethrin. Fire Saf Sci 10:239-252. https://doi.org/10.3801/IAFSS.FSS.10-239

60. Blomqvist P, Rosell L, Simonson M (2004) Emissions from fires part I: fire retarded and non-fire retarded TV-sets. Fire Technol 40:39-58. https://doi.org/10.1023/ B:FIRE.0000003315.47815.cb

61. Andersson B, Markert F, Holmstedt G (2005) Combustion products generated by hetero-organic fuels on four different fire test scales. Fire Saf J 40:439-465. https:// doi.org/10.1016/j.firesaf.2005.03.002

62. Aljumaiah O, Andrews GE, Abdullahi A, Mustafa B, Phylaktou HN (2010) Wood crib fires under high temperature low oxygen conditions. Fire Explos Hazards 6:1044 1055. https://doi.org/10.3850/978-981-08-7724-8_15-05

63. Aljumaiah O, Jordan J, Andrews GE, Phylaktou HN (2008) The development of a technique for the combustion of wood in a high temperature low oxygen compartment. In: Proceedings of the Saudi international innovation conference, Leeds, UK

64. Aljumaiah O, Andrews GE, Alshammari S, Burell G, Cox M, Phylaktou HN (2010) Toxic emissions from folded cotton towel fires in a low ventilation compartment. Fire Explos Hazards 6:792-803. https://doi.org/10.3850/978-981-08-7724-8_11-07

65. Andrews GE, Boulter S, Daham B, Mmolawa MD, Burrell G, Ledger J, Phylaktou HN (2007) Toxic gas measurements using FTIR for combustion of COH materials in air starved enclosed fires. In: Gokalp I (ed) Proceedings of the third European combustion meeting, Chania, Crete 
66. Aljumaiah O, Andrews GE, Alqahtani AM, Husain BF, Singh P, Phylaktou HN (2010) Air starved acrylic curtain fire toxic gases using an FTIR. Fire Explos Hazards 6:804-816. https://doi.org/10.3850/978-981-08-7724-8_11-08

67. Andrews GE, Daham B, Mmolawa MD, Boulter S, Mitchell J, Burrell G, Ledger J, Gunamusa W, Boreham RA, Phylaktou HN (2005) FTIR investigations of toxic gases in air starved enclosed fires. Fire Saf Sci 8:1035-1046. https://doi.org/10.3801/ IAFSS.FSS.8-1035

68. Ribière P, Grugeon S, Morcrette M, Boyanov S, Laruellea S, Marlair G (2012) Investigation on the fire-induced hazards of Li-ion battery cells by fire Calorimetry. Energy Environ Sci 5:5271-5280. https://doi.org/10.1039/c1ee02218k

69. Wesolek D, Kozlowski R (2002) Toxic gaseous products of thermal decomposition and combustion of natural and synthetic fabrics with and without flame retardant. Fire Mater 26:215-224. https://doi.org/10.1002/fam.800

70. Blomqvist P, Hertzberg T, Tuovinen H, Arrhenius K, Rossel L (2007) Detailed determination of smoke gas contents using a small-scale controlled equivalence ratio tube furnace method. Fire Mater 31:495-521. https://doi.org/10.1002/fam.946

71. Blomqvist P, Hertzberg T, Dalene M, Skarping G (2003) Isocyanates, Aminoisocyanates and amines from fires - a screening of common materials found in buildings. Fire Mater 27:275-294. https://doi.org/10.1002/fam.836

72. Hertzberg T, Blomqvist P, Dalene M, Skarping G (2003) Particles and isocyanates from fires. SP Fire technology report 2003:05, Borås. p 51

73. Al-Sayegh W, Aljumaiah O, Andrews GE, Phylaktou HN (2015) Chapter 17: PVC cable fire toxicity using the cone calorimeter. Fire Sci Technol 10:175-182. https:// doi.org/10.1007/978-981-10-0376-9_17

74. Blomqvist P, Sandinge A (2018) Experimental evaluation of fire toxicity test methods. RISE report 2018:40, Borås, p 137

75. Blomqvist $P$ et al (2014) Detailed study of distribution patterns of polycyclic aromatic hydrocarbons and isocyanates under different fire conditions. Fire Mater 38:125-144. https://doi.org/10.1002/fam.2173

76. Amon F, Simonson M, Blomqvist P (2014) Fire effluent contaminants, predictive models, and gap analysis. SP report 2014:20, Borås, p 51. https://doi.org/10.13140/RG.2.2. 19779.09761

77. ISO 19701:2013, Methods for sampling and analysis of fire effluents, ISO, Geneva

78. ISO 19702:2015, Toxicity testing of fire effluents - guidance for analysis of gases and vapours in fire effluents using FTIR gas analysis, ISO, Geneva

79. US Environmental Protection Agency (1999) EPA/625/R-96/010b: compendium method TO-15: determination of volatile organic compounds (VOCs) in air collected in specially-prepared canisters and analyzed by gas chromatography/mass spectrometry (GC/MS), p 63

80. Dhabbah AM, Badjah-Hadj-Ahmed AY, Stec AA, Hull TR (2019) Comparison of different sampling techniques for the identification of aromatic hydrocarbons from fire effluents. Am J Anal Chem 10:23-37. https://doi.org/10.4236/ajac.2019.101003

81. Larson TV, Koenig JQ (1994) Wood smoke: emissions and noncancer respiratory effects. Annu Rev Public Health 15:133-156. https://doi.org/10.1146/annurev.pu.15.050194.001025

82. Austin CC, Wang D, Ecobichon DJ, Dussault G (2001) Characterization of volatile organic compounds in smoke at experimental fires. J Toxicol Environ Health Part A 63:191-206. https://doi.org/10.1080/15287390151101547 
83. Friedli HR, Atlas E, Stroud VR et al (2001) Volatile organic trace gases emitted from North American wildfires. Glob Biogeochem Cycles 15:435-452. https://doi.org/ 10.1029/2000GB001328

84. Romagnoli E, Barboni T, Santoni PA, Chiaramonti N (2014) Quantification of volatile organic compounds in smoke from prescribed burning and comparison with occupational exposure limits. Nat Hazards Earth Syst Sci 14:1049-1057. https://doi.org/ 10.5194/nhess-14-1049-2014

85. Urbanski SP, Hao WM, Baker S (2008) Chapter 4: chemical composition of wildland fire emissions. Dev Environ Sci 8:79-107. https://doi.org/10.1016/S14748177(08)00004-1

86. Garcia-Hurtado E, Pey J, Borrás E et al (2014) Atmospheric PM and volatile organic compounds released from Mediterranean shrubland wildfires. Atmos Environ 89:8592. https://doi.org/10.1016/J.ATMOSENV.2014.02.016

87. Demeestere K, Dewulf J, De Witte B, Van Langenhove H (2007) Sample preparation for the analysis of volatile organic compounds in air and water matrices. J Chromatogr A 1153:130-144. https://doi.org/10.1016/J.CHROMA.2007.01.012

88. US Environmental Protection Agency (1999) Determination of volatile organic compounds (VOCs) in ambient air using specially prepared canisters with subsequent analysis by gas chromatography. In: Compendium of Methods for the Determination of Toxic Organic Compounds in Ambient Air EPA/625/R-96/010b, 2nd ed. US EPA, Cincinnati, $\mathrm{OH}, \mathrm{p} 32$

89. European Committee for Standardization (1997) EN:1948:1-3. Stationary source emissions- Determination of the mass concentration of PCDDs/PCDFs, $\mathrm{p} 68$

90. US Environmental Protection Agency (1996) Method 0023A: sampling method for polychlorinated dibenzo-p-dioxins and polychlorinated dibenzofuran emissions from stationary sources. US EPA, Cincinnati, p. 31

91. Ballard JMEnvironmental Monitoring Systems Laboratory (Las Vegas) (1986) Performance of RCRA method 8280 for the analysis of dibenzo-p-dioxins and dibenzofurans in hazardous waste samples. U.S. Environmental Protection Agency, Environmental Monitoring Systems Laboratory, Las Vegas

92. US Environmental Protection Agency (2017) Method 201A: PM10 and PM2.5 - constant sampling rate procedure, $\mathrm{p} 44$

93. US Environmental Protection Agency (2017) Method 202: condensable particulate matter, p 27

94. US Environmental Protection Agency (1999) EPA/625/R-96/010b: compendium method TO-13A. Determination of polycyclic aromatic hydrocarbons (PAHs) in ambient air using gas chromatography/mass spectrometry (GC/MS), p 84

95. Bhargava A, Dlugogorski BZ, Kennedy EM (2002) Emission of polyaromatic hydrocarbons, polychlorinated biphenyls and polychlorinated dibenzo-p-dioxins and furans from fires of wood chips. Fire Saf J 37:659-672. https://doi.org/10.1016/S03797112(02)00025-5

96. Gullett BK, Touati A, Hays MD (2003) PCDD/F, PCB, HxCBz, PAH, and PM emission factors for fireplace and woodstove combustion in the San Francisco Bay region. Environ Sci Technol 37:1758-1765. https://doi.org/10.1021/es026373c

97. Lee RGM, Coleman P, Jones JL et al (2005) Emission factors and importance of PCDD/Fs, PCBs, PCNs, PAHs and PM 10 from the domestic burning of coal and wood in the UK. Environ Sci Technol 39:1436-1447

98. Liljelind PER, Söderström G, Hedman B et al (2003) Method for multiresidue determination of halogenated aromatics and PAHs in combustion-related samples. Environ Sci Technol 37:3680-3686. https://doi.org/10.1021/es0263994 
99. Szulejko JE, Kim K-H, Brown RJC, Bae M-S (2014) Review of progress in solvent-extraction techniques for the determination of polyaromatic hydrocarbons as airborne pollutants. TrAC Trends Anal Chem 61:40-48. https://doi.org/10.1016/ J.TRAC.2014.07.001

100. He J, Balasubramanian R (2009) Determination of atmospheric polycyclic aromatic hydrocarbons using accelerated solvent extraction. Anal Lett 42:1603-1619. https:// doi.org/10.1080/00032710902993886

101. Iavicoli I, Chiarotti M, Bergamaschi A et al (2007) Determination of airborne polycyclic aromatic hydrocarbons at an airport by gas chromatography-mass spectrometry and evaluation of occupational exposure. J Chromatogr A 1150:226-235. https:// doi.org/10.1016/J.CHROMA.2006.08.010

102. Strandberg B, Julander A, Sjöström M et al (2018) Evaluation of polyurethane foam passive air sampler (PUF) as a tool for occupational PAH measurements. Chemosphere 190:35-42. https://doi.org/10.1016/J.CHEMOSPHERE.2017.09.106

103. Singh DP, Gadi R, Mandal TK (2012) Characterization of gaseous and particulate polycyclic aromatic hydrocarbons in ambient air of Delhi, India. Polycycl Aromat Compd 32:556-579. https://doi.org/10.1080/10406638.2012.683230

104. Nizzetto L, Lohmann R, Gioia R et al (2008) PAHs in air and seawater along a North-South Atlantic transect: trends, processes and possible sources. Environ Sci Technol 42:1580-1585. https://doi.org/10.1021/es0717414

105. Yuan XX, Jiang Y, Yang CX et al (2017) Determination of 16 kinds of polycyclic aromatic hydrocarbons in atmospheric fine particles by accelerated solvent extraction coupled with high performance liquid chromatography. Chin J Anal Chem 45:1641-1647. https://doi.org/10.1016/S1872-2040(17)61047-8

106. Crimmins BS, Baker JE (2006) Improved GC/MS methods for measuring hourly PAH and nitro-PAH concentrations in urban particulate matter. Atmos Environ 40:6764 6779. https://doi.org/10.1016/J.ATMOSENV.2006.05.078

107. Kaupp H, McLachlan MS (1998) Atmospheric particle size distributions of polychlorinated dibenzo-p-dioxins and dibenzofurans $(\mathrm{PCDD} / \mathrm{Fs})$ and polycyclic aromatic hydrocarbons (PAHs) and their implications for wet and dry deposition. Atmos Environ 33:85-95. https://doi.org/10.1016/S1352-2310(98)00129-0

108. Kaupp H, Towara J, McLachlan MS (1994) Distribution of polychlorinated dibenzop-dioxins and dibenzofurans in atmospheric particulate matter with respect to particle size. Atmos Environ 28:585-593. https://doi.org/10.1016/1352-2310(94)90034-5

109. Kouimtzis T, Samara C, Voutsa D et al (2002) PCDD/Fs and PCBs in airborne particulate matter of the greater Thessaloniki area, N. Greece. Chemosphere 47:193-205. https://doi.org/10.1016/S0045-6535(01)00291-0

110. Wallenhorst T, Krau $\beta$ P, Hagenmaier H (1997) PCDD/F in ambient air and deposition in Baden-Württemberg, Germany. Chemosphere 34:1369-1378. https://doi.org/ 10.1016/S0045-6535(97)00434-7

111. Li Y, Jiang G, Wang Y et al (2008) Concentrations, profiles and gas-particle partitioning of polychlorinated dibenzo-p-dioxins and dibenzofurans in the ambient air of Beijing, China. Atmos Environ 42:2037-2047. https://doi.org/10.1016/J.ATMOSENV.2007.12.005

112. Rushdi AI, El-Mubarak AH, Lijotra L et al (2017) Characteristics of organic compounds in aerosol particulate matter from Dhahran city, Saudi Arabia. Arab J Chem 10:S3532-S3547. https://doi.org/10.1016/J.ARABJC.2014.03.001

113. Oliveira C, Pio C, Alves C et al (2007) Seasonal distribution of polar organic compounds in the urban atmosphere of two large cities from the North and South of Europe. Atmos Environ 41:5555-5570. https://doi.org/10.1016/J.ATMOSENV.2007.03.001 
114. Fine PM, Cass GR, Simoneit BRT (2004) Chemical characterization of fine particle emissions from the wood stove combustion of prevalent United States tree species. Environ Eng Sci 21:705-721. https://doi.org/10.1089/ees.2004.21.705

115. Hays MD, Geron CD, Linna KJ et al (2002) Speciation of gas-phase and fine particle emissions from burning of foliar fuels. Environ Sci Technol 36:2281-2295. https:// doi.org/10.1021/es0111683

116. Dmitrienko SG, Gurariy EY, Nosov RE, Zolotov YA (2001) Solid-phase extraction of polycyclic aromatic hydrocarbons from aqueous samples using polyurethane foams in connection with solid-matrix spectrofluorimetry. Anal Lett 34:425-438. https:// doi.org/10.1081/AL-100102584

117. Saleh A, Yamini Y, Faraji M et al (2009) Ultrasound-assisted emulsification microextraction method based on applying low density organic solvents followed by gas chromatography analysis for the determination of polycyclic aromatic hydrocarbons in water samples. J Chromatogr A 1216:6673-6679. https://doi.org/10.1016/ J.CHROMA.2009.08.001

118. Qiu Y-W, Zhang G, Liu G-Q et al (2009) Polycyclic aromatic hydrocarbons (PAHs) in the water column and sediment core of Deep Bay, South China. Estuar Coast Shelf Sci 83:60-66. https://doi.org/10.1016/J.ECSS.2009.03.018

119. Haleyur N, Shahsavari E, Mansur AA et al (2016) Comparison of rapid solvent extraction systems for the GC-MS/MS characterization of polycyclic aromatic hydrocarbons in aged, contaminated soil. MethodsX 3:364-370. https://doi.org/10.1016/ J.MEX.2016.04.007

120. Cornelissen G, Rigterink H, ten Hulscher DEM et al (2001) A simple Tenax ${ }^{\circledR}$ extraction method to determine the availability of sediment-sorbed organic compounds. Environ Toxicol Chem 20:706-711. https://doi.org/10.1002/etc.5620200403

121. Koh C-H, Khim JS, Kannan K et al (2004) Polychlorinated dibenzo-p-dioxins (PCDDs), dibenzofurans (PCDFs), biphenyls (PCBs), and polycyclic aromatic hydrocarbons (PAHs) and 2,3,7,8-TCDD equivalents (TEQs) in sediment from the Hyeongsan River, Korea. Environ Pollut 132:489-501. https://doi.org/10.1016/ J.ENVPOL.2004.05.001

122. Götz R, Enge P, Friesel P et al (1994) Sampling and analysis of water and suspended particulate matter of the river Elbe for polychlorinated dibenzo-p-dioxins (PCDDs) and dibenzofurans (PCDFs). Chemosphere 28:63-74. https://doi.org/10.1016/00456535(94)90201-1

123. Liu Y, Peng P, Li X et al (2008) Polychlorinated dibenzo-p-dioxins and dibenzofurans (PCDD/Fs) in water and suspended particulate matter from the Xijiang River, China. J Hazard Mater 152:40-47. https://doi.org/10.1016/J.JHAZMAT.2007.06.071

124. Stachel B, Gotz R, Herrmann T et al (2004) The Elbe flood in August 2002-occurrence of polychlorinated dibenzo-p-dioxins, polychlorinated dibenzofurans (PCDD/F) and dioxin-like PCB in suspended particulate matter (SPM), sediment and fish. Water Sci Technol 50:309-316

125. ISO 13914:2013, Soil quality: determination of dioxins and furans and dioxin-like polychlorinated biphenyls by gas chromatography with high-resolution mass selective detection (GC/HRMS), ISO, Geneva

126. Jacq K, David F, Sandra P, Klee MS (2008) Analysis of volatile organic compounds in water using static headspace-GC/MS. Agilent Technologies, Environmental Application Note, p 16

127. Rothweiler B (2014) Analysis of volatile organic compounds in environmental waters using the agilent 7697A headspace and 7890B/5977A GC/MS. Agilent Technologies, Application Note, p 6 
128. US Environmental Protection Agency (2006) EPA/SW-846 method 8260B: standard operating procedures: volatile organic analysis in soil/sediment by GC/MS, p 85

129. Portable GC-MS Team (2015) Perkin Elmer Application note: volatile organic compound screening in soil using SPME-GC/MS, p 3

130. Huang $\mathrm{Z}$ fa (2017) Perkin Elmer application note: determination of volatile organic compounds in soils by HS-GC/MS, p 4

131. Supelco (1996) Bulletin 865B: GC/HPLC analyses of organic compounds in drinking water: US EPA procedures, p 6

132. Retamal M, Costa C, Suárez JM, Richter P (2013) Multi-determination of organic pollutants in water by gas chromatography coupled to triple quadrupole mass spectrometry. Int J Environ Anal Chem 93:93-107. https://doi.org/10.1080/ 03067319.2011 .637195

133. Lopez-Avila V, Young R, Beckert WF (1994) Microwave-assisted extraction of organic compounds from standard reference soils and sediments. Anal Chem 66:10971106. https://doi.org/10.1021/ac00079a027

134. Barile FA, Dierickx PJ, Kristen U (1994) In vitro cytotoxicity testing for prediction of acute human toxicity. Cell Biol Toxicol 10:155-162. https://doi.org/10.1007/ BF00757558

135. Stec AA, Hull TR (2009) Fire toxicity and its assessment. In: Wilkie CA, Morgan A (eds) Fire retardancy of polymeric materials, 2nd edn. CRC Press, Boco Raton, pp 453-477

136. ISO 13344:2015. Estimation of the lethal toxic potency of fire effluents, ISO, Geneva

137. ISO 13571:2012, Life-threatening components of fire: guidelines for the estimation of time to compromised tenability in fires, ISO, Geneva

138. National Research Council (2014) Assessment of ecotoxicity. In: A framework to guide selection of chemical alternatives. National Academies Press (US), Washington, DC, pp 1-14

139. Landrigan PJ, Lioy PJ, Thurston G et al (2004) Health and environmental consequences of the World Trade Center disaster. Environ Health Perspect 112:731-739. https://doi.org/10.1289/ehp.6702

140. McGee JK, Chen LC, Cohen MD et al (2003) Chemical analysis of World Trade Center fine particulate matter for use in toxicologic assessment. Environ Health Perspect 111:972-980. https://doi.org/10.1289/ehp.5930

141. Stec AA, Dickens K, Barnes JLJ, Bedford C (2019) Environmental contamination following the Grenfell Tower fire. Chemosphere 226:576-586. https://doi.org/10.1016/ j.chemosphere.2019.03.153

142. ISO 17512-1:2008 Soil quality: avoidance test for determining the quality of soils and effects of chemicals on behaviour-part 1: test with earthworms (Eisenia fetida and Eisenia andrei), ISO, Geneva

143. 145. ISO 17512-2: 2011. Soil quality: avoidance test for determining the quality of soils and effects of chemicals on behaviour-part 2: test with collembolans (Folsomia candida), ISO, Geneva

144. Amorim MJB, Novais S, Rombke J, Soares AMVM (2008) Enchytraeus albidus (Enchytraeidae): a test organism in a standardised avoidance test? Effects of different chemical substances. Environ Int 34:363-371. https://doi.org/10.1016/ j.envint.2007.08.010

145. Amorim MJB, Novais S, Römbke J, Soares AMVM (2008) Avoidance test with Enchytraeus albidus (Enchytraeidae): effects of different exposure time and soil properties. Environ Pollut 155:112-116. https://doi.org/10.1016/J.ENVPOL.2007.10.028 
146. Novais SC, Soares AMVM, Amorim MJB (2010) Can avoidance in Enchytraeus albi$d u s$ be used as a screening parameter for pesticides testing?. Chemosphere 79:233-237. https://doi.org/10.1016/J.CHEMOSPHERE.2010.01.011

147. Owojori OJ, Healey J, Princz J, Siciliano SD (2011) Can avoidance behavior of the mite Oppia nitens be used as a rapid toxicity test for soils contaminated with metals or organic chemicals?. Environ Toxicol Chem 30:2594-2601. https://doi.org/10.1002/ etc. 658

148. Loureiro S, Soares AMVMVM, Nogueira AJAJA (2005) Terrestrial avoidance behaviour tests as screening tool to assess soil contamination. Environ Pollut 138:121-131. https://doi.org/10.1016/j.envpol.2005.02.013

149. Zidar P, Bozic J, Strus J (2005) Behavioral response in the terrestrial isopod Porcellio scaber (Crustacea) offered a choice of uncontaminated and cadmium-contaminated food. Ecotoxicology 14:493-502. https://doi.org/10.1007/s10646-005-0005-9

150. Moreira-Santos M, Donato C, Lopes I, Ribeiro R (2007) Avoidance tests with small fish: determination of the median avoidance concentration and of the lowest-observedeffect gradient. Environ Toxicol Chem . https://doi.org/10.1897/07-094

151. ISO (2007) ISO 11348: 2007. Water quality: determination of the inhibitory effect of water samples on the light emission of Vibrio fisheri (Luminiscent bacteria test)

152. Hertzberg, T, Blomqvist, $\mathrm{P}$, Nosratabadi, R (2006) Influence of $\mathrm{HCl}$ and PVC-smoke on isolated and perfused guinea pig lungs. SP fire technology report 2006:57, p 39

153. Little EE, Calfee RD (2002) Environmental implications of fire-retardant chemicals. Columbia, Misssouri, p 9

154. Little EE, Calfee RD (2002) Environmental persistence and toxicity of fire-retardant chemicals, Fire-Trol GTS-R and Phos-Chek D75-R to Fathead Minnows. Columbia, Misssouri, p 52

155. Babrauskas V (2020) Combustion toxicity regulations for construction products. J Fire Sci 38:96-100. https://doi.org/10.1177/0734904119880472

156. Huggett C, Levin BC (1987) Toxicity of the pyrolysis and combustion products of poly(vinyl chlorides): a literature assessment. Fire Mater 11:131-142. https://doi.org/ $10.1002 /$ fam. 810110303

157. Hirata T, Inoue M, Fukui Y (1992) Pyrolysis and combustion toxicity of wood treated with CCA. Wood Sci Technol 27:35-47. https://doi.org/10.1007/BF00203408

158. Tame NW, Dlugogorski BZ, Kennedy EM (2007) Formation of dioxins and furans during combustion of treated wood. Prog Energy Combust Sci 33:384-408. https:// doi.org/10.1016/J.PECS.2007.01.001

159. Lavric ED, Konnov AA, De RJ (2004) Dioxin levels in wood combustion - a review. Biomass Bioenergy 26:115-145. https://doi.org/10.1016/S0961-9534(03)00104-1

160. Wasson SJ, Linak WP, Gullett BK et al (2005) Emissions of chromium, copper, arsenic, and PCDDs/Fs from open burning of CCA-treated wood. Environ Sci Technol 39:8865-8876. https://doi.org/10.1021/es050891g

161. Weil ED (2011) Fire-protective and flame-retardant coatings: a state-of-the-art review. J Fire Sci 29:259-296. https://doi.org/10.1177/0734904110395469

162. Lowden L, Hull T (2013) Flammability behaviour of wood and a review of the methods for its reduction. Fire Sci Rev 2:4. https://doi.org/10.1186/2193-0414-2-4

163. Wilkins E, Murray F (1980) Toxicity of emissions from combustion and pyrolysis of wood. Wood Sci Technol 279:267-279. https://doi.org/10.1007/BF00383455

164. https://www.pinfa.eu/sustainability/environment/

165. Simonson M, Blomqvist P, Boldizar A, Möller K, Rosell L, Tullin C, Stripple H, Sundqvist JO (2000) Fire-LCA model: TV case Study. SP report 2000:13, p 222. http s://doi.org/10.13140/RG.2.2.24917.12000 
166. Simonson M, Andersson P, Blomqvist P, Stripple H (2005) Environmental assessment of fires in products using the Fire-LCA model. Fire Saf Sci 8:1071-1082. https:// doi.org/10.3801/IAFSS.FSS.8-1071

167. Andersson P, Simonson M, Tullin C, Stripple H, Sundqvist JO, Paloposki T (2004) Fire-LCA guidelines. SP fire technology SP report 2004:43, p 99

168. Simonson M, Stripple H (2000) LCA study of TV sets with V0 and HB enclosure material. In: Proceedings of the IEEE international symposium on electronics and the environment. https://doi.org/10.1109/ISEE.2000.857626

169. Simonson M, Stripple H (2000) LCA study of flame retardants in TV enclosures. Flame Retard 2000:159-170

170. Simonson M, Tullin C, Stripple H (2002) Fire-LCA study of TV sets with V0 and HB enclosure material. Chemosphere 46:737-744. https://doi.org/10.1016/S00456535(01)00238-7

171. Simonson M, Andersson P, Rosell L, Emanuelsson V, Stripple H (2001) Fire-LCA model: cables case study. SP report 2001:2, p 129

172. Simonson M, Andersson P, Emanuelsson V, Stripple H (2003) A life-cycle assessment (LCA) model for cables based on the Fire-LCA model. Fire Mater 27:71-89. https:// doi.org/10.1002/fam.818

173. Andersson P, Simonson M, Rosell L, Blomqvist P, Stripple H (2003) Fire-LCA model: furniture case study, SP report 2003:22, p 182. https://doi.org/10.13140/RG.2.2.11809. 92006

174. Andersson P, Simonson M, Blomqvist P, Stripple H (2004) Fire-LCA model: furniture case study. Flame Retard 2004:15-26

175. Hamzi R, Londiche H, Bourmada N (2008) Fire-LCA model for environmental decision-making. Chem Eng Res Des 86:1161-1166. https://doi.org/10.1016/ j.cherd.2008.05.004

176. Amon F, Gehandler J, Stahl S, Tomida M, Meacham B (2016) Development of an environmental and economic assessment tool (Enveco tool) for fire events. National Fire Protection Research Foundation FPRF-2016-09, p 99

177. Chettouh S, Hamzi R, Innal F, Haddad D (2016) Interest of the theory of uncertain in the Dynamic LCAFire methodology to assess fire effects. Phys Procedia 55:207-214. https://doi.org/10.1016/j.phpro.2014.07.030

Publisher's Note Springer Nature remains neutral with regard to jurisdictional claims in published maps and institutional affiliations. 